\title{
English Language, the Nigerian Education System and Human Development
}

\author{
Juliana Chinwe Njoku \\ http://dx.doi./org/10.4314/ujah.v18i2.12
}

\section{Abstract}

The role English language plays in human development in Nigeria is the focal point of this paper. Basically, language is the most frequently used and the most highly developed form of human communication. Through language, people interact, share ideas and express their feelings. Without language, man would be incapable of a sustained and result oriented thinking. Education is unarguably an essential instrument for change and human development. At different levels of schooling in formal education, students are equipped with life-long knowledge and skills that would enable them realize their full potentials as human beings. However, all forms of education (formal, informal and non-formal) are realized through language; hence, language and education are inseparable. In the Nigerian polity, English language plays the role of a second language, considering the multilingual nature of the country. English is also the language of instruction in the Nigeria education system. Not only is it the language of instruction, it is also a compulsory subject and a yardstick for evaluating a learner's school performance. The normal teachinglearning process thrives on effective communication between the teacher and the learner. No matter how expertly, learning experiences are selected and organized, the ultimate objective of the teaching-learning exercise would not be achieved if the language of instruction is unfamiliar to the leaner. This is where English language comes in. English language is indispensable to 
education in Nigeria, thus, it is a veritable tool for human development.

Keywords: English Language, Veritable tool, Human Development, Education, and Nigeria

\section{Introduction}

Language allows people to develop a sense of self, and to interact with others in the community. Language is the means through which knowledge is transmitted. Every form of education; formal, informal or non-formal is expressed and acquired through language. Through education, man's potentials are developed; skills, knowledge and expertise that will enable man become more productive and creative in his environment are acquired. Through education man is equipped to engage in profitable ventures that would earn him higher income and improve his standard of living. Man is enabled to gain access to better health care and other social services that add value to his life. Thus, education is regarded as a powerful instrument for human and national development.

However, the issue of education cannot be discussed without the language through which the concepts are expressed. Because no matter how expertly the learning experiences are selected and organized, the ultimate objective of the teaching-learning exercise would not be achieved if the language of instruction is unfamiliar to the learner. English is the language of education in Nigeria. It is the language of instruction from upper primary education, through secondary and tertiary education in Nigeria. The state of English as a Second Language in Nigeria coupled with the numerous roles it plays, compels every Nigerian citizen to learn and to speak it. This paper therefore submits that if English language is the medium through which the concepts in education are expressed and 
acquired, then, it is a primary instrument for human development in Nigeria. English language has not only engineered human development through education, it has also conferred on Nigerians other significant privileges both on the home front and the global scene.

Based on this back drop, the paper examines the role of formal education in human development, the place of English language in the Nigerian education system and the role it plays in human development in Nigeria. The paper also examines the other benefits literacy in English offers Nigerians. The paper concludes that the relevance of English language in our nation cannot be neglected. It is the foundation for all aspects of human and national development. Therefore, efforts should be made to ensure that literacy in English is attained by all and sundry in Nigeria.

\section{Clarification of Concepts}

The term 'development' simply means "growth", 'transformation' or "positive change'. It is a progression from a low state to a much higher state. Development has many aspects such as: economic, social, environmental, political and human dimensions. All of them interplay to create a balance that is needed for a sustainable earth. Hence, Business Dictionary defines development as "the process of economic and social transformation that is based on complex cultural and environmental factors and their interactions" (web). National development cuts across economic growth, attainment of economic targets such as: increase in Gross National Product (GNP) and Gross Domestic Product (GDP). These are indicators of National Progress in many countries. 
Human development on the other hand is about expanding the richness of human life, rather than the economy in which human beings live. Human development focuses on people. It is a process in which man transforms himself and acquires the capacity to live a better, more rewarding and fulfilling life.

United Nations Development Programme (UNDP) in Human Development Report (HDR), defines human development as "ability to lead long and healthy lives, to be knowledgeable, to have access to resources needed for a decent standard of living and to be able to participate in the life of the community" (web). The process of human development should at least create an environment for people, individually and collectively, to develop their full potentials and to have a reasonable chance of leading productive and creative lives that they value. Human development is about improving people's well being. It is about enlarging people's choices.

Although there is no comprehensive and concise way of measuring human progress, certain factors are indicators to human development such as:

- Reduction in poverty index

- Increase in access to education

- Increase in gross national income

- Increase in life expectancy

- Gender empowerment and

- Access to social services needed for a decent standard living.

Human development focuses on improving the lives people lead, rather than assuming that economic growth will lead automatically 
to greater opportunity for all. Human development agenda 2030 is in alignment with Sustainable Development Goals (SDGS) 2030 which states that, there is a critical need for transformational change in development, so that no one is left behind.

\section{Education and Human Development}

Education is defined as "the act or process of imparting or acquiring general knowledge, developing the powers of reasoning and judgment, and generally of preparing oneself and others for mature life" (dictionary reference. co). Inko-Taria, also defines education as "a process of developing a person in all aspects of life, to be able to function properly as an individual and be useful to society" (P.30). From the above definitions, we can see that education is a life-long process which enables the continuous development of a person's capabilities as an individual and as a member of society.

Education can take three different forms: informal, non-formal and formal. The focus of this paper is on formal education which is associated with schooling. It comprises all forms of organized learning experiences acquired by an individual in a school structure, under the guidance of a teacher. Bergevin in Ezele defines formal education as "systematically arranged educational programmes in which students are enrolled or registered to follow established courses, either on full-time or part-time basis. The programmes are normally held within the walls of institutions" (12).

At the different levels of schooling in formal education, students are equipped with life-long knowledge and skills that would enable them realize their full potentials as human beings. They are taught 
numeracy and literacy skills, citizenship, scientific, technological, entrepreneurial and other skills that would enable them become either employable in the world of work or become self reliant. Students are also made to develop: reasoning ability, critical thinking, autonomy, creativity, self direction, ability to make value judgments and work co-operatively with others. (Njoku: p.97). We can see from the forgoing that it is through education that man can achieve growth and development. Through education people acquire relevant skills that promote developmental efforts. Education gives knowledge, expertise, skills and maximized performance. It is a means of promoting self sufficiency and independence.

The economic and social advantages of education cannot be over emphasized. They include: faster growth of (GNP) Gross National Production, higher family income, higher productivity, a more skilled labour force, better wage employment, self employment and so on. Good quality education enables people to transform their lives and the society in which they live. Education raises income levels and improves standard of living.

Eyisi asserts that good education is the key to modernization and development. Njoku and Izuagba concur to this by stating that it is only through education and civilization that man can achieve growth and development for himself and his community. The quality of education in a country underpins the growth of individual and national wealth and helps to drive economic development. For each government, education is a long term investment, but a citizen's individual ambition is a prime factor. Euromonitor report on Nigeria indicates that individuals regard education as the best way to escape poverty. So, many Nigerians 
aspire to be educated, hence we have educated professionals in various fields of human activity. Through education, Nigeria has been provided with a vibrant work force that can compete effectively anywhere in the world.

The issue of education cannot be discussed successfully without the language which serves as the medium of instruction. The skills and knowledge which education provides for human development will not be possible without the language through which the concepts are expressed. This is where English language comes in, because in Nigeria, English is the language of education. Since we cannot talk about education without the language through which the learning experiences are relayed, and English being the language of education in Nigeria, one can therefore state categorically that English language is a primary tool for human development in Nigeria.

\section{The Place of English Language in the Nigerian Education System}

A good knowledge of the socio-political history of Nigeria will enable one understand how English language came into Nigeria and occupied a colossal position in the Nigerian education system. Our country is made up of multilingual and multi-ethnic nationals wielded together for the benefit of the colonial administration. English language was then adopted as a language of necessity to enable the British run their colonial government. Clarks and interpreters were trained and those who wished to work with the colonial masters strived to learn English.

The missionaries were the first to establish schools in Nigeria. Their main aim then was to train people who will propagate the 
gospel. When the British government took over the running of the schools in Nigeria, they harmonized the subjects taught in the different missionary schools. They also came up with a policy that made English language a core subject as well as the language of instruction in the 1882 and 1887 education ordinances (Njoku and Izuagba: 2001).

Form this point, many Nigerians strove to learn English as competence in it was a meal ticket. In fact it was a yardstick for employment during the colonial era. After independence, the Nigerian system of education did not change much from what it was during the colonial era. English language remained the pivot of education in Nigeria. It is the language of instruction from upper primary education through secondary, to tertiary education in Nigeria. It is the language through which all other subjects in the curriculum are taught. Not only is English language a compulsory subject in secondary education, a credit pass in it is a compulsory condition for securing admission into Nigerian tertiary institutions. Competence in English is seen as an index of academic, excellence. Thus, it is a yardstick for measuring learners' academic performance. More so, before any student can graduate from the tertiary institutions in Nigeria, they must pass the course Use of English.

From the foregoing, we have seen that English language is the bedrock upon which education in Nigeria is hinged. Suffice it then to say that English is indispensable to education in Nigeria.

\section{English Language and Human Development in Nigeria}

Having identified education as a major tool in human development earlier, it is essential to note that the language through which 
education is acquired is also of utmost importance. As shown in the last section, English is the language of education in Nigeria. Every form of education is expressed and acquired through language. It is through English language that formal education is acquired in Nigeria. In other words it is through English language that the skills and knowledge needed for human development is acquired. Therefore, by extension, English language is a primary instrument for human development in Nigerian.

The benefits of education (acquired via English language) are enormous; they include: Improved social relations

- Better job opportunities

- Higher family income

- Higher productivity

- Access to better health facility

- Improved standard of living

- Ability to participate in the life of the community

Besides these benefits, English language has conferred on Nigerians other privileges that bear on human development as well as national development, both on the home front and on the global scene. On the home front, English language is essentially regarded as a unifying factor. It has allowed Nigerians to co-exist peacefully even in their diversity. It is this peaceful co-existence that engenders development either on individual or national basis.

Considering the multilingual nature of the country, the communication crises that would have occurred among people from different linguistic background is bridged by the use of English. It is possible for Nigerians irrespective of their ethnic backgrounds, to study or work in any part of the country. The same 
goes for teachers/workers who could also choose to teach/work in any part of the country without fear of language barrier.

English language has advanced Nigerians economically. Locally, people engage in trading and other business activities to increase their economic power and improve their standard of living. This has been successful because of the use of English. Globally, people engage in international businesses facilitated by the use of English. Again, the status of English as a second language in Nigeria has attracted foreign investment. According to Euromonitor, the Foreign Direct Investment (FDI) inflows from the English speaking countries such as USA and UK are typically high in the countries that use English as their $2^{\text {nd }}$ language. Thus, Nigeria has benefitted in this regard because of their use of English. Examples of such foreign investors are; Mobil, Shell, Nexen in the oil and gas sector. Other sectors that are boosting the nation`s economy are - information technology (IT) services, banking and telecommunications. As stated in the Euromonitor:

Companies such as MTN communication and Microsoft have found that both Nigeria and Pakistan offer a more attractive business environment than many other countries as a result of these countries higher levels of English proficiency among other factors (8).

This confirms the fact that improved English language skills help to attract more foreign investments. These investments in turn create more job and career opportunities for Nigeria Euromonitor report also confirms that Nigerians believe that learning English in particular offers great opportunity for career advancement and higher pay. In affirmation to this statement, Olofin opines, "Before 
any Nigerian can occupy any position of eminence today, he must be 'English compliant'". He further avers that promotions and ability to advance one's career through national and international communication is tied to one's education and particularly to one's ability to speak good English (137). This is in line with Osuafor's assertion that "people who could speak and write English had more chances of being employed than those who could not" (23).

English language provides a link to the global world. Being a major language of communication in the global world, it offers the people of this nation the benefit of participating in global affairs. Access to adequate information is gained on a global level.

English language has also assisted technological development in Nigeria. Ike avers that English language is the window to the world of science and technology. It is the language used in space science and computing technology. There is easy knowledge transfer now in quantities and at speed unimaginable in the past. There is digital communication of massive data bases via the internet, smart phones, fax machines, television, print media and so on. One can easily connect to databases anywhere in the world from the comfort of our rooms. Although some innovations to technology have negative effects, their advantages far outweigh the disadvantages. Most organizations, industries and parastatals have gone digital. It makes administration easy and provides easier method for storing and retrieving information. Nigerians are active participants in this digital world because of their knowledge of English language. They are also able to read and interpret such information or instructions enclosed in scientific literature and put them into use. 
Literacy in English language is very important to all round human development in Nigeria. Anyone who wishes to be relevant in the Nigerian polity as well as the global world should learn English by all means. Therefore, a more functional approach should be adopted for the effective teaching and learning of English language in our schools.

\section{Theoretical Framework}

This work is hinged on the theory of Community Language Learning (CLL) developed by Charles Curran in 1972. Community Language Learning is a language teaching approach based on counseling techniques. Here, the hierarchical student- teacher relationship is dispensed with and the counselor- client relationship is adopted. The idea is to eliminate any sense of challenge or risktaking from the emotionally delicate client, which theoretically would loosen him or her to learn a second language without difficulty. In other words, it is an approach that alleviates anxiety and threat and other personal problems a person encounters in learning a second language

CLL was inspired by Carl Roger's view of education; that all living creatures are motivated to live up to their potentials, but human beings are often impeded by their environment and personal problems. Once the impediments are eliminated, the individual can develop his full potentials. Thus, this theory is relevant to this paper in the sense that when the impediments to the learning of English are removed, Nigerians would learn it with ease and as such develop their full potentials both as individuals and as members of the society. 
This approach emphasizes the use of meaningful conversations in teaching and learning language in real communicative situations. It democratizes the relationships between learners and teachers and reduces anxiety. This paper strongly submits that the use of the CLL approach in the teaching and learning of English as a second language in Nigeria would go a long way in improving and entrenching the use of English in every segment of the society.

\section{Problems of Teaching and Learning English Language in Nigeria}

Most often, language teachers at all levels of education in Nigeria encounter many problems in their attempt at improving the teaching and learning of English language. Some of the problems include: lack of resources for language teaching, inadequate knowledge of current trends in the teaching and learning of a second language, inconsistencies in the language policy provision on education, attitude and psychological problems on the part of the learners and unprofessionalism in handling the subject. These are just a few of the problems as space would permit.

For us to achieve good success in English language education, these problems should be tackled headlong. For instance, the teaching of English should be handled by professionals only; it should not be open to 'every comer' in the teaching profession. Again, the government should provide the needed resources for teaching language in our schools. Such resources include text books, tape recorders, flannel boards, interactive/magic boards, and language laboratories and so on. On training of teachers, Nwachukwu opines that "there is need to update knowledge and skills in a world that is continually progressing in all spheres of life, if not, we will find ourselves recycling information that is long 
outdated" (64). So, teachers need to be exposed to current trends in language teaching, they should also be exposed to all body of knowledge, skills and resources that would enable them teach effectively the English language in our schools. As for tackling the attitude and psychological problems of the learners, the use of the CLL method would go a long way in restoring the confidence of the learners as well as reduce their anxiety.

This paper strongly advocates that all the segments of the Nigerian society should have equal access to effective teaching and learning of the English language. The present dichotomy which exists between students in urban and rural areas should be closed. If the CLL method should be adopted by all language teachers, all Nigerian students would be enabled to acquire adequate functional and communicative competence in the use of English language, irrespective of where they reside in the country.

The role of English language in the life of an average Nigerian is quite immeasurable. For one to be relevant both in the Nigerian polity and the world at large, one has to attain some level of competence in the use of English language.

\section{Conclusion}

Many issues have been raised in this paper some of which are: the communicative role of language, education as an instrument for change and human development, the importance of English as the language of education in Nigeria and the benefits of literacy in English to both human and national development. The paper concludes that the knowledge, skills, and expertise gained through education are only made possible by the language through which they are acquired. Hence English language and education in 
Nigeria cannot be separated. They both work together to bring about human and national development in Nigeria.

Again, English language has not only advanced Nigerians educationally, it has also advanced them socially, politically, economically, technologically and otherwise. It has conferred a lot of privileges on Nigerians both on the home front and the global scene.

\author{
Juliana Chinwe Njoku \\ Alvan Ikoku Federal \\ College of Education, Owerri \\ juliana_njoku@yahoo.com
}

\title{
Works Cited
}

Euronomonitor international. "English Language Qualitative Indicators: Cameroon, Nigeria, Rwanda, Bangladesh and Pakistan". 2010 web. www.euromonitor.com

Eyisi, Joy C. "Language national development" the case of English language in Nigeria". In Chinua Achebe Journal of Development Studies. Vol 1,78-86. 2000. Print.

Ezele, N.E. "Adult and Non-formal Education in Nigeria: Challenges and Prospects. In international Journal of Management and Social Sciences. Vol.2 No.1 pp12-17. 2013. Print.

Human Development Report (HDR). "What is Development?" HDR Out Reach. 2015. Web. 
Ike, Ndubuisi J. Applied linguistics. Abuja: Wilbest Educational Publishers. 2007. Print.

Inko-Taria, D.C. "Education: An Important Tool for the Elimination of Violence against Women in Nigeria" In International Journal of Education Research and Administration. Vol 7. No. 4, pp29-35. 2010. Print.

Njoku, T.U \& Izuagba, A.C. New Approaches to English Language and Literature Teaching. Owerri: versatile publisher. 2001. Print.

Njoku. J.C. "Exploring Language and Education as Powerful Tools for Women Empowerment and Breaking the Cycle of Poverty". In International Journal of Gender and Development Issues. Vol. 1 No. 3 pp94 -102. 2014. Print.

Nwachukwu, U.I. Challenges in the Teaching \& Learning of English in Nigeria. Owerri: Cel-Bez publishers. 2007. Print.

Olofin, Alabi Oluseji. "Effects of English Language on National Development" In Greener Journal of Social Sciences. Vol.2. No. 4, pp. 134-139. 2012. Web.

Osuafor. C.C. The English language in Nigeria. Owerri: Great versatile publishers. 2002. Print. 